\title{
The Use of the Module System in Ancient Egyptian Architecture
}

\author{
Yoshifumi YASUOKA*
}

\begin{abstract}
This article aims to prove that the module system in the architectural design of Ancient Egypt was in use as early as the New Kingdom Period. I first extract the essence of the Egyptian module system evident in the elevation drawings of shrines on papyrus from the Late Period to the Greco-Roman Period, and I then extrapolate its use in works of earlier periods, mainly in depictions of shrines, furniture pieces and smaller wooden shrines, but also in a stone shrine from the time of Thutmose III. The result of this preliminary analysis shows that the use of the Egyptian module system can be traced to as early as the Eighteenth Dynasty and that more precise documentations for wooden and stone shrines known to us would be helpful to further clarify the principles of such design practice.

The article later defines the characteristics of the Egyptian module system by comparing it to the Vitruvian module system, whose origin hitherto has been said to be Greek. The schematic diagrams of the Doric and Ionic systems clearly show the difference in methods of defining the dimensions of each component of a design. The Doric system represents a radial pattern, in which a single module defines the dimensions of most parts. This is identical to the module system of Ancient Egyptian shrines. The Ionic system, on the other hand, designates several dimensions as references, and as such, this system is to be regarded as multi-modular. In the historical development of the architectural styles, in order to create more elaborate system of design that would suit each culture's architectural style and philosophy, the Doric system was perhaps based on the Egyptian system, and the Ionic system developed from the Doric.
\end{abstract}

Keywords: module system, proportion, Vitruvius, architecture, Ancient Egypt

\section{Introduction}

Proportion has been a key element of architectural design in western civilization since antiquity (Padovan 1999). Ever since an architect became a significant profession in a society, epoch-making architects such as Marcus Vitruvius Pollio, Andrea Palladio, Sebastiano Serlio, and Le Corbusier have endeavoured to set a standard in design methods by publishing their own architectural treatises. In such writings, the application of a proportional method called the "module system" played the main role in defining architectural form (Mallgrave 2006; Mallgrave and Contandriopoulos 2008). The concept of the module system is explained for the first time in "De architectura", written by Roman architect Vitruvius in $c$. twenty BC (Vitruvius III-IV). The module system is a method of defining the major and minor parts of buildings by means of proportions, in which the base unit defines other parts as its multiples or fractions. This base unit was given the name "modulus" by the Romans and thus called "module" today, and the column diameter is usually designated as the module. The module system was developed for the design of sacred and civil architecture, where

* Superlative Postdoctoral Fellow of Japan Society for the Promotion of Science, Graduate School of Engineering, the University of Tokyo

1 For the editions of Vitruvian treatise, see Fensterbusch 1991; Fleury et al. 1990-2004. 
forms were regulated more strictly than those of ordinary buildings.

Vitruvius also stated that his treatise was the result of studies of architectural treatises written by earlier Greek architects, such as Hermogenes (Hoepfner and Schwandner 1990), which implies that the concept of the module system already existed in the Hellenistic Period. Further, it is commonly believed that the Ancient Greeks learned to systematically and effectively construct monumental stone architecture from the Ancient Egyptians (Coulton 1977; Wilson Jones 1989, 106-151). I also see the possibility that the Greek principles of design were also based upon principles that already existed in Ancient Egypt (Yasuoka 2017). Supporting this view, Joachim Friedrich Quack recently discovered some papyri that can be regarded as manuals for customs surrounding temple use, names and descriptions of rooms, or decoration of temples. One document, the so-called "Book of the Temple", is a manual for priests, describing the ideal contents of an Egyptian temple (Quack 2009, 221-229). Another fragmentary document of drawings and text includes numbers indicating how the temple wall should be divided proportionally so that the decoration schemes would fit properly (Quack 2014, 17-27). Both documents are dated to the Greco-Roman Period (332 BC-395 AD), but the anachronistic language and the grammar used in these documents imply that at least some parts of the contents had already existed in the New Kingdom Period.

Adding to this evidence, there are also some models and drawings of architectural elements from the Late Period (664-332 BC), such as column capitals, shrines, and statues, ${ }^{2}$ which show the remains of guidelines that were drawn or carved to depict the outlines of the desired form on unworked block (Edgar 1905, 137-150; 1906; Tomoum 2005). Such guidelines were either singular lines marking certain axes or grids that helped workers to control the proportions of a sculpture. Moreover, the use of the grid for laying out human and animal figures is attested as early as the Eleventh Dynasty (twenty-first century BC), although it is still unclear whether the grid system can be regarded as equivalent to the module system described by Vitruvius (Robins 1994). Thus, scholars have assumed that the temple plans and elevations were designed using a simple grid or a module system (Lacher-Raschdorff 2014, 113-117; Raven 2003, 53-69; Wysocki 1984, fig. 6; Arnold and Arnold 1979, 17-18, pl. 27.a; Carlotti 1995, 65-126). However, the results of the analyses are rather unconvincing, and another approach seems wanting. ${ }^{3}$

In this paper, I will focus on the design method of Ancient Egyptian shrines, as some drawings clearly indicate the use of a module system during the design process. Since a shrine housed a divine statue at the temple's innermost location, and was thus the temple's most important architectural element, it is plausible that certain ideal forms existed and that their designs were controlled by some kinds of proportional rules. In order to re-establish lost knowledge of these design principles, this study will firstly extract the essence of the design method from these drawings, and then verify the validity of this method with the actual two- and three-dimensional works dated to the Late

\footnotetext{
There are some indications that the statues belonged to the architectural discipline, and thus, it is comprehensible that Vitruvius also makes an analogy of temples to the human body, of column styles to gender, and relates them through the module system as the common means of design. It is noteworthy that these concepts are already existent in Ancient Egypt. I intend to demonstrate this in a future article.

3 Regarding the problems in assuming the use of a grid in a plan, see Yasuoka 2016. The use of a grid for a plan is attested for in urban-scale design or in the juxtaposition of buildings in a larger temple complex, but never for the design of a single building.
} 
Period and earlier.

\section{Elevation Drawings of a Wooden Shrine}

One tantalizing piece of evidence that shows the use of grids for architectural design is a pair of elevation drawings of a shrine on papyrus (UC27934) from the Petrie Museum of Egyptian Archaeology. One shows the front elevation and the other the side (Petrie 1926a, 46, pl. 54; 1926b, pls. 1-2; Smith and Stewart 1984, 54-64; Yasuoka 2015). The two elevation drawings, which once formed a single papyrus roll, are drawn on a large sheet of papyrus $(54 \mathrm{~cm} \times c .165 \mathrm{~cm})$ with a grid laid out (Fig. 1). The absence of notations on this papyrus indicates that all the information should be extracted solely from the drawing. In the case of UC27934, the width of the posts, the thickness of the crossbeam and the height of the platform were drawn to occupy exactly one square, which acted as the module of the shrine. The widths and heights of the major parts were also designed by simple numbers of the module. The height of the shrine proper including the podium and the curved roof is $17+1 / 2$ modules, which is double the front width of the shrine at the base. The height of the cornice of the shrine is given $1+1 / 2$ modules in the front view ${ }^{4}$ and that of the canopy 2 modules. The top of the cornice of the canopy is 18 modules and the top of the uraeus is 21 . The width of the side view at the base is 9 modules. Smaller parts were divided into halves, thirds, quarters, sixths and eighths. The width of the crossbeam at its top end is exactly 1 module shorter than the bottom width of the opening. Thus, the diminution rate of the width is $1: 14+1 / 2(\mathrm{~W}: \mathrm{H})$.

Another drawing of a shrine is found on a verso of a papyrus (UC32374) depicting a scene from the "Book of the Dead" (Tait 2004, 573-582). It is drawn on a much smaller scale $(22.5 \mathrm{~cm}$ × c. $19 \mathrm{~cm}$ ) (Tait 2004, 573; for colour plate see Trope et al. 2005, 153). The shrine was drawn without the help of the grid, but with accompanying numbers and dimensions written in demotic (Fig. 2). As John W. Tait has demonstrated already, the discrepancy between the drawn length and the value of the designated numbers should be noted (Tait 2004, 579-581).

There are two types of numerical instructions observed on this papyrus. The first type is a set of simple numbers. The system used here to determine the form of the shrine is principally the same module system as that in UC27934: A pair of numbers written outside the shrine indicates the relative measurements of the overall height and width as "17 1/2"5 and "9", respectively. The thickness of the crossbeam and the width of the posts operate as the module and are thus designated as " 1 ". Larger parts are mostly given whole numbers, and smaller parts are given fractions consisting of halves, thirds, quarters, and sixths, which imply the use of 18 or 24 divisions. Within the frame of the posts and crossbeam, there are also indications of the bottom and the top width, read as "9" and " 8 " respectively, which means that the width of the shrine diminishes from the bottom to the top by 1 module. ${ }^{6}$ Thus, the rate of the diminution of the opening would be $1: 13+$ $5 / 6$ (bottom) or $1: 14+5 / 6$ (top). ${ }^{7}$

\footnotetext{
4 In the side view, it is depicted as $1+1 / 3$ modules. This is the only place where the front and the side views are not coherent.

5 Note that this value is identical with the total height in the "Ghurob Shrine Papyrus".

6 Tait either omits or misinterprets these numbers, maybe due to the presumption that this writing is a continuation of the actual dimension beginning from the right end of the frame.

Unlike the "Ghurob Shrine Papyrus", this small scaled drawing as well as the examples introduced below do not allow us to determine whether the intended point of reference is at the top or bottom of the crossbeam. In this article, I will
} 
The second type of numerical instruction on the papyrus is the specification of actual dimension in the divine cubit (mh-ntr). Curiously, there were at least three values visible on the drawing, although one is sufficient to define the dimensions of the rest of the parts. ${ }^{8}$ These numbers were intended to give the actual dimensions to the shrine planned without scale by the module system. The relationship of these three dimensions to the module system is difficult to explain at the moment, since the written dimensions do not have the same proportion to the corresponding modules. Given that the readings of the numbers are all correct, the three dimensions show the following ratio to the corresponding modules:

The length of the crossbeam: $\quad 1+1 / 6$ cubit $/ 8$ modules $=0.146 \mathrm{c} / \mathrm{m}$

The width of the opening at the base: $1+1 / 3+1 / 12$ cubit $/ 9$ modules $=0.157 \mathrm{c} / \mathrm{m}$

The total height of the shrine: $\quad 3+1 / 16$ cubit $/ 17+1 / 2$ modules $=0.175 \mathrm{c} / \mathrm{m}$

At the first sight, the small discrepancies among them seem dismissible as the result of rounding up the cubit values, however, a simple subtraction of the first two would give a module value of $1 / 4 \mathrm{c}$ which is far different from any of the three. It could be that the scribe has jotted down three different scales for consideration.

Furthermore, the height of the parts described in modules would add up to $17+1 / 12$ rather than $17+1 / 2$ as indicated separately. ${ }^{9}$ Tait also demonstrated that the accuracy of the drawing to the given modules are not consistent (Tait 2004), which indicates that the elevation is subjectively drawn and that it was used by one person or a limited number of people who knew or were able to complement the lacking information by communication, to which we have no more access.

Both items are dated, either palaeographically or stylistically, to terminus post quem $664 \mathrm{BC}$, i.e. contemporary with the period when the Greeks had frequent interactions with the Egyptians. ${ }^{10}$ Thus, they do not necessarily prove the Egyptian origin of the module system in architecture. There are, however, some important rules that can be postulated from these drawings:

1. The width of the post and/or the height of the beam is given 1 module, acting as the module.

2. The width of the main structure is given a round number.

3. The total height is a simple number but does not have to be a round number.

4. The details are simple divisions of the module, defined by unit fractions that were conventionally used in Ancient Egypt (including 2/3 and 5/6).

One should also bear in mind that these elevation drawings, which show common principles between the planning method of shrines and of furniture that takes the form of a shrine, were drawn and used in different situations. The "Ghurob Shrine Papyrus" is drawn on a grid to convey to the observer the ideal form of the shrine, and is meant to be a theoretical drawing. Since the

indicate both values.

8 There might have been more specifications of this kind that are effaced or lost today.

9 Perhaps the remaining value was reserved for the height of the curved roof, which is usually omitted in the front view.

${ }^{10}$ For the Egyptian and Greek relations, see Barletta 2001; Hall 1997. 
elevations were drawn on the recto of an unusually large format of papyrus, leaving the verso of the papyrus totally unused, they most likely formed a part of the pattern book kept in a temple. In contrast, the elevation drawing with the demotic notations are drawn on a verso of a former "Book of the Dead", which was eventually re-used as a part of the cartonnage. The drawing also provides the actual dimensions in cubit along with the module system, which indicates that the elevation was drawn on a scrap of papyrus for an actual project and that the drawing was dispensable and re-used for another purpose after the project was completed.

\section{Depictions of Shrines, Furniture Pieces, and Small Shrines from the Late Period}

The use of the module system can also be confirmed in the depictions of shrines and furniture from the same period. The author will analyse only a number of selected examples from the existing publications that include either reliable line drawings or orthogonal photos. ${ }^{11}$ A good example is a relief depicting a shrine (JdE40627), in which a goddess is squatting to bear a child (Fig. 3) (Spiegelberg 1929, pl. 2; for colour plate see Strouhal 1992, 17 (fig.)). From the artistic style of the human-headed goddess in the middle and the cow-headed goddesses on both sides, this relief can be dated to the Greco-Roman period. It is noteworthy that the grid, on which the shrine was laid out, is partly visible on the front surface and fully visible on the other sides. ${ }^{12}$ The horizontal guidelines are also recognizable, firstly by the scores in red ink at both ends of the frame formed by the two outer vertical axes, and secondly by the horizontal scores that run through them. ${ }^{13}$

The manner of denotation is equivalent to that of the "Ghurob Shrine Papyrus", but the proportion adheres rather to that of the drawing with demotic notations. 1 module corresponds with the width of the post and the thickness of the crossbeam. The total height including the podium but excluding the blank rectangle at the top, which were intended for the row of uraei, can be estimated as $17+1 / 3+1 / 4$ (or $17+1 / 2+1 / 6$ ). The width of the opening at the base is 7 modules and 6 at the top. There seems to be an underlying ratio of $1: 2$ in the overall structure including the uraei $(10: 20)$ as well as in the shrine proper $(17+1 / 2+1 / 6: 9)$. The height of the opening measures 14 modules, which makes the diminution ratio $1: 14$ (bottom) or $1: 15$ (top). The thickness of the moulding measures $1 / 4$ module and the cornice $1+1 / 3$ module. Interestingly, the rectangle area of the relief is 24 modules wide and 21 modules high, whose ratio would be $8: 7$.

Another example shows a portable shrine on the temple wall in Athribis, built under Ptolemy XII (Fig. 4) (El-Sayed and El-Masry 2012, pl. 1). ${ }^{14}$ Overlaying a hypothetical grid on the published photo, the thickness of the crossbeam, the width of the post, and the height of the platform all have one module. The width of the opening is 10 at the bottom and $9+1 / 2$ at the top, diminishing by $1 / 2$

${ }^{11}$ Due to the various states of documentation of the objects selected here, it was not possible to present them in a consistent manner. Some materials lack records of measurements or line drawings, so orthogonal photographs were selected for analysis. Analysis by superimposing a grid, however, allows us to consider the proportionality without considering its size or measurements. Also, there are also other examples of depictions of shrines that are worth analysing, but they must be precisely documented first. See for example Favard-Meeks 1991, pl. 33; Chassinat 1918, 3, pl. 14; Junker 1958, figs. 28-29, 115-116.

12 This object remains hitherto insufficiently documented, but one may observe this object on display at the Egyptian Museum in Cairo.

${ }^{13}$ This is also a common future in the "Ghurob Shrine Papyrus", where the scores are marked to draw the grid lines. See Yasuoka 2015.

${ }^{14}$ The slightest difference is seen in the use of sistrum columns, which implies that the honoured deity in this shrine was a goddess, probably the goddess Repyt, to whom the temple was dedicated. 
module every $15+1 / 4$ (bottom) or $16+1 / 4$ (top) modules in height. The height of the cornice is most likely $1+1 / 2$ modules for the shrine and $2+1 / 2$ for the canopy. The uraeus of the canopy, which seems to be left unfinished, is 3 modules high. The height of the shrine proper excluding the uraei is $18+1 / 6$. The total height, including the canopy but excluding the uraeus, is 21 modules, whereas the total height of the structure is 24 modules. Here again, the underlying ratio between the width and the height including the uraei is $1: 2(12: 24)$. The maximal width of the shrine, at the platform, is 18 , thus the rectangle of this structure forms a $4: 3$ (24:18) ratio, including the uraeus on the canopy, or $7: 6(21: 18)$ excluding it. The carrying-poles seem to be extended for 18 modules on either side, so that the length of the carrying pole would be 3 times the width of the platform.

It is also noteworthy that the shrine-like podium, on which the shrine rests, is designed according to a different module system. If one regards the width of the post as the module, then the width would be 13 modules and the height 12 . The height of the frame construction is $10+1 / 2$ and the height of the cornice including the moulding $1+1 / 2$. The diminution of the frame is $1+1 / 2: 9$ $+2 / 3$ (bottom) or $10+5 / 12$ (top). Perhaps the aimed value was $1+1 / 2$ in $10+1 / 2$, which is $1: 7$.

One of the earliest shrines with a carrying pole at the middle height of the shrine is depicted on the so-called "Oracle Papyrus" in the Brooklyn Museum (Fig. 5) (47.218.3) (Parker 1962, pl. 1). This papyrus is dated to the reign of Psamtik I, but the depicted shrine bears the cartouche of Taharqa $\left(N f r-t m-i b-R^{c}\right)$. It is to be noted that the posts of the shrine are not inclined before the Twenty-Sixth Dynasty. The segment of papyrus where the shrine was depicted is largely missing, however the essential shrine components are available, therefore the shrine may be securely reconstructed by applying the grid. Assuming the width of a post is 1 unit, as was the case with the shrine drawings on papyrus, the width of the opening is 10 modules. The height of the opening is $14+1 / 2$ modules. The total height of the shrine proper excluding the podium is $17+1 / 2$, the upper and lower boards each having a thickness of $1 / 4$. The tent-pole columns of the canopy are placed on the axis of the grids. The carrying pole extends by 24 modules from the podium to each direction, which makes their ratio $4: 3: 4$.

There are also some examples of depictions of wooden shrines in the animal necropolis of Tuna el-Gebel, which are worth documenting and analysing in future. ${ }^{15}$ A smaller version of such a shrine (JdE91108) dated to the Late Period was indeed found at the animal necropolis of Saqqara (Fig. 6) (Green 1987, 5-6, fig. 4). Taking the width of the post as the module, the width of the opening would be 10 modules and its height would be $13+1 / 4$ modules. The thickness of the crossbeam is also 1 module. The width of the opening is $8+1 / 2$ modules at the top, diminishing by $1+1 / 2$ modules. Thus the diminution rate would be $1+1 / 2: 13+1 / 4$ (bottom) or $14+1 / 4$ (top). The total height of the shrine is $17+1 / 2$ modules. The width of the shrine proper (12 modules) and the height (16 modules) have the ratio of $3: 4$.

There are also wooden chests and boxes, for which the Ancient Egyptians preferred to use a shrine form. ${ }^{16}$ One of the well-documented chests was found recently by the excavation led by the

\footnotetext{
${ }^{15}$ I am indebted to Dr. Mélanie Floßmann-Schütze for this information.

${ }^{16}$ The proportional analysis of the wooden examples is, in general, difficult due to the distortion caused by changes in humidity and pressure through time. As the reader will see, the overlaid grid on the wooden examples do not always show clear tendencies as in the depictions or in the stone examples, and thus the precise modules intended by the Ancient Egyptians for such examples may vary slightly, especially in smaller parts, which can only be verified by
} 
Charles University in Prague (Fig. 7). ${ }^{17}$ From the private tomb of Iufaa in Abusir, the chest can be securely dated to the Twenty-Sixth Dynasty (Bareš and Smoláriková 2008, 61, 221, pl. 40.a-b). Here, the bottom width of the "opening" is also 10 times the width of the post. The height of the "opening" measures $14+1 / 4$ modules, and the width diminishes by $2 / 3$ module at the top. The height of the cornice is $1+1 / 4$ modules. The paintings of the shrine are also laid out using the module. ${ }^{18}$ The total height is $16+3 / 4$ modules, perhaps leaving $3 / 4$ module for the imaginary podium.

Another, similar chest from the Late Period is kept at Musée du Louvre (E2773) (Killen 1994, 83-85, fig. 82). ${ }^{19}$ Superimposing a grid on the drawing, which is based on the measurement taken by Pieter De Bruyne (Fig. 8), makes clear that the width of the "opening" at the bottom is 10 times the width of the post and 9 at the height of the crossbeam. ${ }^{20}$ The height of the "opening" would have been planned as $14+1 / 3$ modules. The thickness of the crossbeam can be seen as $5 / 6$ module and the height of the cornice including the moulding as $1+1 / 2$. Thus, the total height of this chest is $16+1 / 2$ modules, again leaving 1 module for the imaginary podium. The ratio between the total width and height is again $3: 4$.

Looking only at the proportional tendencies of the examples of the Late Period, two proportional rules are recognizable: The first is that the width and the height of the major parts are designed to have simple ratios. The second rule is that the two numbers in ratios often have the relationship of " $n: n+1$ ", i.e. $1: 2,2: 3,3: 4$, etc. This implies that the one of the two dimensions defines the other by adding or subtracting 1 module.

\section{Did the Module System Exist in the New Kingdom Period?}

After confirming the use of the module system for shrines and shrine-like furniture pieces from the Late Period, it is also important to determine whether this method can be applied to the works preceding the Late Period. Here again, I must limit the example to finds sufficiently documented by means of technical drawings or orthogonal photographs. One of the most important threedimensional representations of shrines in the New Kingdom Period is the small shrine (JdE61481) of Tutankhamun (1332-1323 BC) (Fig. 9). Although the shrine has suffered a distortion over time, overlaying the grid on the orthogonal photographs (Eaton-Krauss and Graefe 1985, pls. 4, 10-13) provides evidence that the same design principle was used; the posts, crossbeam, and possibly the sled or the platform of the shrine act as the module, and the width and height of the shrine are planned with simple multiples of the module. In the front view, the space between the posts is 6 modules, whereas in the side view, the width of the opening is extended by 2 modules for a total of 8 modules. The height up to the moulding is 12 modules, the thickness of the moulding $1 / 6$, and the

accurate measuring in the future. In this article, however, it should suffice to show the use of the module system.

17 The author would like to thank Prof. Dr. Ladislav Bareš for sending the pictures and drawings of this find. The drawing of the author shown in this article is based on the valuable information provided by the Czech excavation team.

${ }^{18}$ Examples of such painted chest can also be found in funerary papyri and tomb decorations. The Royal Museum of Ontario, Toronto 910.85.236.1-13 (Amenemhat); The British Museum, London EA9908,2 (Tashereten-Menu). See Bianchi et al. 1988, 235-236, pl. 23 (Cat. 126); Seipel 1989, 174 (no. 140); Lembke 2014, pls. 2,2, 5,2, 9,2.

19 Another important example (TR29.12.25.6) is known but remains undocumented in the Egyptian Museum, Cairo (Capart 1947, pl. 797; Killen 1994, 85).

${ }^{20}$ Killen's drawings presented in his volumes on the Egyptian furniture are schematic and cannot be used for proportional analysis in this study. 
cornice $1+1 / 2$ modules. The ratio among the width of the front and the side and the height is $4: 5: 6$.

A chest of Tutankhamun (Fig. 10) also indicates the use of the module system. In the front view, the width of the opening is 10 times the width of the post. The total height, excluding the lid, would then be 8 modules. The height of the cornice is also designed as 1 module, which makes the ratio between the width and the height $2: 3$. The width of the opening in the side view is extended by $1+$ $1 / 2$ modules. The smaller parts can be regarded as the multiples of either $1 / 2,1 / 3,1 / 6$ of the module.

I further confirmed the use of the single module system in a stone shrine (Fig. 11). This shrine was commissioned by Thutmose III to be built at El-Kab, now in the Fitzwilliam Museum at Cambridge (E.40.1902; Clarke 1922, 32, pl. 6). ${ }^{21}$ The shrine is hewn from two large blocks of sandstone, which are joined at the lower part of the shrine. Applying the grid to the front elevation of the shrine, if the width of the post $(12.9 \mathrm{~cm} \approx 1 / 4$ cubit $=13.125 \mathrm{~cm})$ can be regarded as 2 modules, the width of the opening $(33.2 \mathrm{~cm})$ can be regarded as 5 modules, the width of the torus $(3.2 \mathrm{~cm}$ ) would be $1 / 2$ module. The height of the opening would be $16+1 / 2$ modules. The height of the cornice with the rim and that of the podium were likely to have been planned as 2 modules. The width ( 9 modules) and the height (18 modules) of the frame formed by the posts and the lintel has a ratio of $1: 2$.

The last and perhaps the earliest example in which I confirmed the use of module system is the wooden table (Fig. 12) likely made at some point between the late Thirteenth to the early Eighteenth Dynasty (c. 1800-1500 BC). On the short side, the width of the opening at the bottom is $7+1 / 2$. The height of the opening is $11+1 / 2$ and the total height can be regarded as $14+1 / 4$. In the side view, the width of the opening is 18 modules and the width of the table surface is $20+$ $1 / 2$ modules. The diminution rate is, in both views, either $1+1 / 2$ in $11+1 / 2$ (bottom) or in $12+$ $1 / 2$ (top).

\section{Comparison with the Vitruvian Module System}

From the analyses above, there is no doubt that a certain module system existed in designing shrines and furniture with a post and lintel structure. It is, thus, significant to compare the Ancient Egyptian use of the module system with the use of the module system for classical architecture described by Roman architect Vitruvius in the first century BC.

Taking the doorways as representative examples of post and lintel construction, the intricacy of the Vitruvian module system (Vitruvius IV, 6) becomes clear. ${ }^{22}$ The descriptions of the Doric (Fig. 13) and Ionic doorways (Fig. 14) show that the width of the jamb is the module, which determines the dimensions of the major parts of the doorways by round numbers of the module and the details by simple fractions. For instance, the height of the doorway is 14 times the module, the thickness of the cymatium is $1 / 6$ of the module. The diminution of the doorway is $1 / 14$ of the module, which is rather obscure for the Greek or Roman use of numbers. ${ }^{23}$ The actual dimensions

\footnotetext{
${ }^{21}$ Although nearly half of this shrine is lost, the essential components have survived to determine the original dimensions of the whole and to make the accurate reconstruction in the museum. For more information on the original state of the shrine, see the field notes (Books F and G) and the drawings of Somers Clarke kept at the Griffith Institute, University of Oxford.

${ }^{22}$ The same characteristics can also be said for the module systems of the Doric and Ionic temples described by Vitruvius in the earlier passages. I will complete the comparative analysis of those passages in the near future.

${ }^{23}$ It is not surprising that Adalbert Birnbaum suggests the reading " $1: 24$ ", which conforms to the conventional use of
} 
of the doorway are not mentioned in the Vitruvian descriptions, which show the same theoretical character as in the "Ghurob Shrine Papyrus". James Coulton, who has analysed the Vitruvian module system, recognizes the "radial pattern" of the Doric temple (Coulton 1975, 70-72, fig. 1), which is analogous to the Egyptian module system observed from the shrines (Fig. 15). ${ }^{24}$ The width of the jamb defines de facto the rest of the dimensions. ${ }^{25}$

The Ionic system, on the contrary, has a somewhat more complicated system, in which the clusters of module systems are related to one another. One aspect that differs clearly from the Egyptian/Doric system is that the width of the jamb in the Ionic system is not the only module from which the dimensions of other parts are defined. Indeed, the width of the door opening, which has a different dimension than the width of the jamb, acts as another dimension of reference and defines many parts. It seems that in the Ionic system, smaller parts defined by the larger parts are relevant to each other. For instance, the small parts of the door-leaves are determined by the thickness of the crossbeam of the door leaf. In the end, the Ionic system builds up clusters of parts - comparable to a family tree-whose base units are related to the base units of the larger parts. ${ }^{26}$ As a result, the architects were able to designate finer dimensions for each part than the conventional $1 / 8,1 / 12$, or $1 / 16$, which are expected in the Doric system. For instance, the smallest part, which is the moulding of the rails, must have been defined as of the $1 / 20+1 / 36(=7 / 90$ or $1 / 12.857 \ldots$ ) of the module, had it been the Doric system. Such a small and complicated dimension was certainly not measured from the original module (the width of the door jamb) as in the Doric system, but would only be realized by repeating the simple fractions through the chain of modules, which in this case is simply taking $1 / 6$ from the height of the rails.

Coulton does not recognize this as a module system, and rather prefers to call it a "successive system" (Coulton 1975). However, it should be recognized as a further development of the Egyptian/Doric system. ${ }^{27}$ In all systems, however, the width or diameter of the support acts as modules and determines the width and height of the structure. The variations from the theory in the practice were generated either by adding or subtracting the modules and its subdivisions, or by including or excluding the details such as the moulding.

Although metrological analysis is impossible due to the limited information regarding the dimensions of these examples, we may safely assume that the base units were not constrained to be a round number of the cubit. Also, the examples of the module system are attested hitherto only for elevation drawings, not for the plan. Thus, the propositions of the previous studies (Arnold and Arnold 1979; Lacher-Raschdorff 2014), which use the grids of 1 cubit as the module for the plans of architecture, should not be considered as evidence of the use of the module system, but rather numbers in Vitruvian culture, although it is clearly written as "1 : 14" (Birnbaum 1914, 28-29). Could the proportion $1: 14$ be an Egyptian influence, originating from the 28-division system of the Egyptian cubit?

${ }^{24}$ Coulton also sees the fine differences among the Doric, Ionian, and Tuscan systems and the buildings with circular plans.

25 At first sight, the height of the cornice seems to define further another element, the projection of cornice, but the height of the cornice can be regarded as equal to the module, which is the width of the jamb.

${ }^{26}$ Whether and how the people differentiated the first and the subsequent dimensions of reference as seen in the Ionic system, remains unknown. In this article, I refer to the first base unit as the module and the subsequent dimensions of reference as the base unit.

${ }^{27}$ Vitruvius also states that the Ionic order was developed after the Doric order (Vitruvius IV, 1.3-8). The invention of Ionic system based upon the Doric system is thus logical, and it is also comprehensible that its inventor, Hermogenes, has been highly praised and remembered by Vitruvius and the subsequent generations. 
a mere indication that the round numbers were used for the planning process. It is noteworthy that the Egyptian grid system appears first in the elevation drawings of human and animal figures in the Eleventh Dynasty. Furthermore, the grid system appears in the architectural drawings of the later period, when it is also confined to the elevation drawings. The same can be stated for the Vitruvian descriptions of the module system, where he usually describes the module system to explain the ideal appearance and proportions of architecture rather than its plan.

\section{Conclusion}

This study has confirmed the use of the module system in various representations of the shrine, i.e. papyrus drawings, relief depictions, wooden furniture, and stone shrines, and has shown that the system was in use in Ancient Egypt as early as the fourteenth century BC. From this study, the following principles of design can be reconstructed:

1. The width of the post acts as the basic unit of the module system, whereas the thickness of the crossbeam and other elements may also be 1 module.

2. The relationship between the front and side length is a difference of a simple number of modules, which is often 1 . The length of the front is usually an even multiple of the module, whereas that of the side is often a single additional module, resulting in an odd number.

3. The total width and the total height of the structure are kept in simple numbers: in most cases round numbers but in some cases include fractions.

4. Other parts can be multiples of the modules, i.e. whole numbers, or divisions of simple unit fractions including $2 / 3$ and $5 / 6$.

5. The diminution of the structure is usually determined by a simple subtraction of 1 module from the bottom width. 1 in 14 or 15 is likely to be the ideal rate.

6. Variations are created by elongating or abridging some elements.

These principles have striking similarities with the module system of the doorways described by Vitruvius. Particularly from the Late Period, the proportion of the shrine becomes more or less consistent: The total height including the podium seems to be set to $17+1 / 2$. The diminution rate of the width is $1: 14-15$. The ratio of the width and the height of the shrine tends to be $1: 2$.

Other examples of wooden or stone shrines, representations of shrines depicted on papyrus (Parker 1962, pl. 1), on temple walls, or actual furniture pieces (Roeder 1914; De Bruyne 1982; Killen 1980; 1994; Baker 1966; Wanscher 1955), ${ }^{28}$ also show tempting results, and could be used to verify this article's hypothesis if they are to be sufficiently documented for analysis in the future. Further research should enable us to clarify and faithfully reconstruct not only more detailed principles of Ancient Egyptian design but also whether these principles can be observed in other architectural elements, such as sculpture, columns, pylons, and obelisks.

Although it should also be kept in mind that there may be alternative methods for designing

\footnotetext{
${ }^{28}$ The author feels the need of verifying the accuracy of these drawings either by himself or by other researchers. He hopes that this study would enhance such opportunities.
} 
architecture, what we have observed here is undoubtedly one of the methods used in Ancient Egypt, and the one that has been passed down to us today.

\section{Acknowledgments}

This research is a partial result of the research project funded by the Japan Society for the Promotion of Science (Grant Number 16J07906 and 17H04947) and ETH Zürich. I wish to thank Dr. Ladislav Bareš for sending the records and photographs of the discovered chest from Abusir, Dr. Christian Leitz for sending the photos of the depicted shrine in Athribis, Dr. Vincent Rondot, Dr. Geneviève Pierrat-Bonnefois, and Dr. Élisabeth Delange for granting me permission for the photographic documentation of the chest and assisting me upon my visit in Louvre. For the permission for documenting the shrine of Thutmose III in the Fitzwilliam Museum, I am very much obliged to Dr. Lucilla Burn, Dr. Helen Strudwick, Dr. Anastasia Christophilopoulou, Ms. Louise Jenkins and Ms. Charis Millet for their kind support. Furthermore, Ms. Ria Verstappen and Ms. Eva Van Regenmortel of the Design Museum Gent (Belgium) have kindly made the materials of the Pieter De Bruyne Archive accessible for me. I would also like to express my gratitude to Dr. Philippe Collombert, Dr. Koichi Kato, Dr. Shinichi Nishimoto, Dr. Joachim Friedrich Quack, and Dr. Kate E. Spence for supporting me on this project.

\section{Bibliography}

Arnold, Di., and Do. Arnold 1979: Der Tempel Qasr el-Sagha, Mainz am Rhein.

Baker, H. S. 1966: Furniture in the Ancient World: Origins and Evolution 3100-475 B.C., London.

Bareš, L., and K. Smoláriková 2008: The Shaft Tomb of Iufaa, Prag.

Barletta, B. A. 2001: The Origins of the Greek Architectural Orders, Cambridge.

Bianchi, R. S. et al. (eds.) 1988: Cleopatra's Egypt: Age of the Ptolemies, Mainz am Rhein.

Birnbaum, A. 1914: Vitruvius und die griechische Architektur, Vienna.

Capart, J. 1947: L'art égyptien: Choix de documents accompagnés d'indications bibliographiques, Brussels.

Carlotti, J.-F. 1995: “Contribution à l'étude métrologique de quelques monuments du temple d'Amon-Rê à Karnak", Cahiers de Karnak 10, 65-126.

Chassinat, É. 1918: Le temple d'Edfou, Cairo.

Clarke, S. 1922: "El-Kâb and Its Temples", Journal of Egyptian Archaeology 8, 16-40.

Coulton, J. J. 1975: "Towards Understanding Greek Temple Design: General Considerations", Annual of the British School at Athens 70, 59-99.

Coulton, J. J. 1977: Ancient Greek Architects at Work, Ithaca.

De Bruyne, P. 1982: Vorm en geometrie in de Oud-Egyptische meubelkunst, Ghent.

Eaton-Krauss, M., and E. Graefe 1985: The Small Golden Shrine from the Tomb of Tutankhamun, Oxford.

Edgar, C. C. 1905: "Remarks on Egyptian 'Sculptors' Models", Recueil de travaux relatifs a la philologie et a l'archéologie égyptiennes et assyriennes 27, 137-150.

Edgar, C. C. 1906: Sculptors' Studies and Unfinished Works, Cairo.

El-Sayed, R., and Y. El-Masry 2012: Athribis, Cairo.

Favard-Meeks, C. 1991: Le temple de Behbeit el-Hagara: Essai de reconstitution et d'interprétation, Hamburg.

Fensterbusch, C. 1991: Vitruv: Zehn Bücher über Architektur, Darmstadt.

Fleury, P. et al. 1990-2004. Vitruve: De l'architecture, vols. 1-10, Paris.

Green, C. I. 1987: The Temple Furniture from the Sacred Animal Necropolis at North Saqqâra 1964-1976, London.

Hall, J. M. 1997: Ethnic Identity in Greek Antiquity, Cambridge.

Hoepfner, W., and E.-L. Schwandner (eds.) 1990: Hermogenes und die hochhellenistische Architektur: Internationales 
Kolloquium in Berlin vom 28. bis 29. Juli im Rahmen des XIII. Internationalen Kongresses für Klassische Archäologie, Mainz am Rhein.

Junker, H. 1958: Der Grosse Pylon des Tempels der Isis in Philä, Vienna.

Killen, G. 1980: Ancient Egyptian Furniture, vol. 1, Warminster.

Killen, G. 1994: Ancient Egyptian Furniture, vol. 2, Warminster.

Lacher-Raschdorff, C. M. 2014: Das Grab des Königs Ninetjer in Saqqara: Architektonische Entwicklung frühzeitlicher

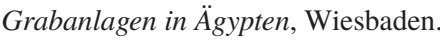

Lembke, K. 2014: Ammoniaca, vol. 2, Wiesbaden.

Mallgrave, H. F. 2006: Architectural Theory, vol. 1, Malden.

Mallgrave, H. F. and C. Contandriopoulos 2008: Architectural Theory, vol. 2, Malden.

Padovan, R. 1999: Proportion: Science, Philosophy, Architecture, London.

Parker, R. A. 1962: A Saite Oracle Papyrus from Thebes in the Brooklyn Museum (Papyrus Brooklyn 47.218.3), Providence.

Petrie, W. M. F. 1926a: Ancient Weights and Measures, London.

Petrie, W. M. F. 1926b: "Egyptian Working Drawings”, Ancient Egypt 1926, 24-27.

Quack, J. F. 2009: "Die Theologisierung der bürokratischen Norm: Zur Baubeschreibung in Edfu im Vergleich zum Buch vom Tempel”, in R. Preys (ed.), 7. Ägyptologische Tempeltagung: Structuring Religion; Leuven, 28. September-1. Oktober 2005, Wiesbaden, 221-229.

Quack, J. F. 2014: "Die theoretische Normierung der Soubassement-Dekoration. Erste Ergebnisse der Arbeit an der karbonisierten Handschrift von Tanis", in A. Rickert and B. Ventker (eds.), Altägyptische Enzyklopädien, Wiesbaden, 17-27.

Raven, M. J. 2003: “The Modular Design of New Kingdom Tombs at Saqqara”, Jaarbericht van het VooraziatischEgyptisch Genootschap (Gezelschap) “Ex Oriente Lux” 37 (2001-02), 53-69.

Robins, G. 1994: Proportion and Style in Ancient Egyptian Art, London.

Roeder, G. 1914: Naos: 70001-70050, Leipzig.

Seipel, W. 1989: ̈̈gypten: Götter, Gräber und die Kunst. 4000 Jahre Jenseitsglaube, Linz.

Spiegelberg, W. 1929: “Die Weihestatuette einer Wöchnerin”, Annales du service des antiquités de l'Égypte 29, $162-165$.

Smith, H. S., and H. M. Stewart 1984: “The Gurob Shrine Papyrus”, Journal of Egyptian Archaeology 70, 54-64.

Strouhal, E. 1992: Life of the Ancient Egyptians, Norman.

Tait, J. W. 2004: “A Papyrus Bearing a Shrine Plan and a Book of the Dead”, in F. Hoffmann and H.-J. Thissen (eds.), Res Severa Verum Gaudium: Festschrift für Karl-Theodor Zauzich zum 65. Geburtstag am 8. Juni 2004, Leuven, $573-582$.

Tomoum, N. S. 2005: The Scupltors' Models of the Late and Ptolemaic Periods: A Study of the Type and Function of a Group of Ancient Egyptian Artefacts, Cairo.

Trope, B. T. et al. 2005: Excavating Egypt: Great Discoveries from the Petrie Museum of Egyptian Archaeology, University College, London, Atlanta.

Wanscher, O. 1955: Mфbelkunsten: Studier i møbeltypernes aestetik og historie, Copenhagen.

Wilson Jones, M. 1989: "Principles of Design in Roman Architecture: The Setting Out of Centralised Buildings", Papers of the British School at Rome 57, 106-151.

Wysocki, Z. 1984: "The Result of Research, Architectonic Studies, and of Protective Work over the Northern Portico of the Middle Courtyard in the Hatshepsut Temple at Deir el-Bahari”, Mitteilungen des Deutschen Archäologischen Instituts, Abteilung Kairo 40, 329-349.

Yasuoka, Y. 2015: "A Reassessment of the "Ghurob Shrine Papyrus'”, Bulletin of the Society for Near Eastern Studies in Japan 58/2, 156-169 (in Japanese with an English abstract).

Yasuoka, Y. 2016: “Cl. Lacher-Raschdorff, Das Grab des Königs Ninetjer in Saqqara. Architektonische Entwicklung frühzeitlicher Grabanlagen in Ägypten, Archäologische Veröffentlichungen 125, Wiesbaden 2014”, Chronique d'Egypte 91, 113-118.

Yasuoka, Y. 2017: “On the Relationship between the Architectural Philosophy in Vitruvius' 'De architectura' and the Surrounding Architectural Cultures: A Comparative Study of the Ancient Egyptian Architectural Media”, Journal of Architecture, Planning and Environmental Engineering (Transactions of AIJ) 82/736, 1581-1589 (in Japanese with an English abstract). 


\section{Figures}
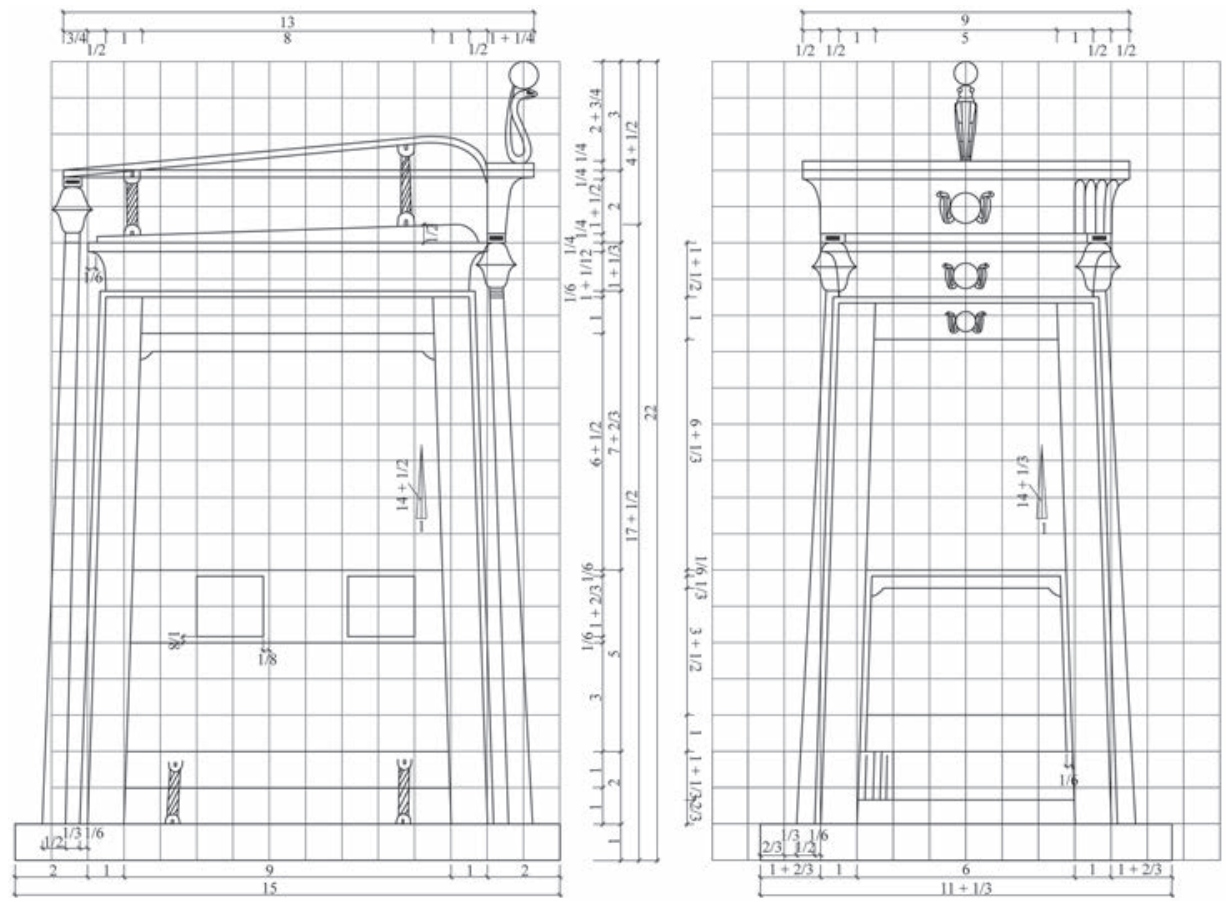

Fig. 1: A Pair of Elevation Drawings of the "Ghurob Shrine Papyrus"

(The Petrie Museum of Egyptian Archaeology, UC27934)

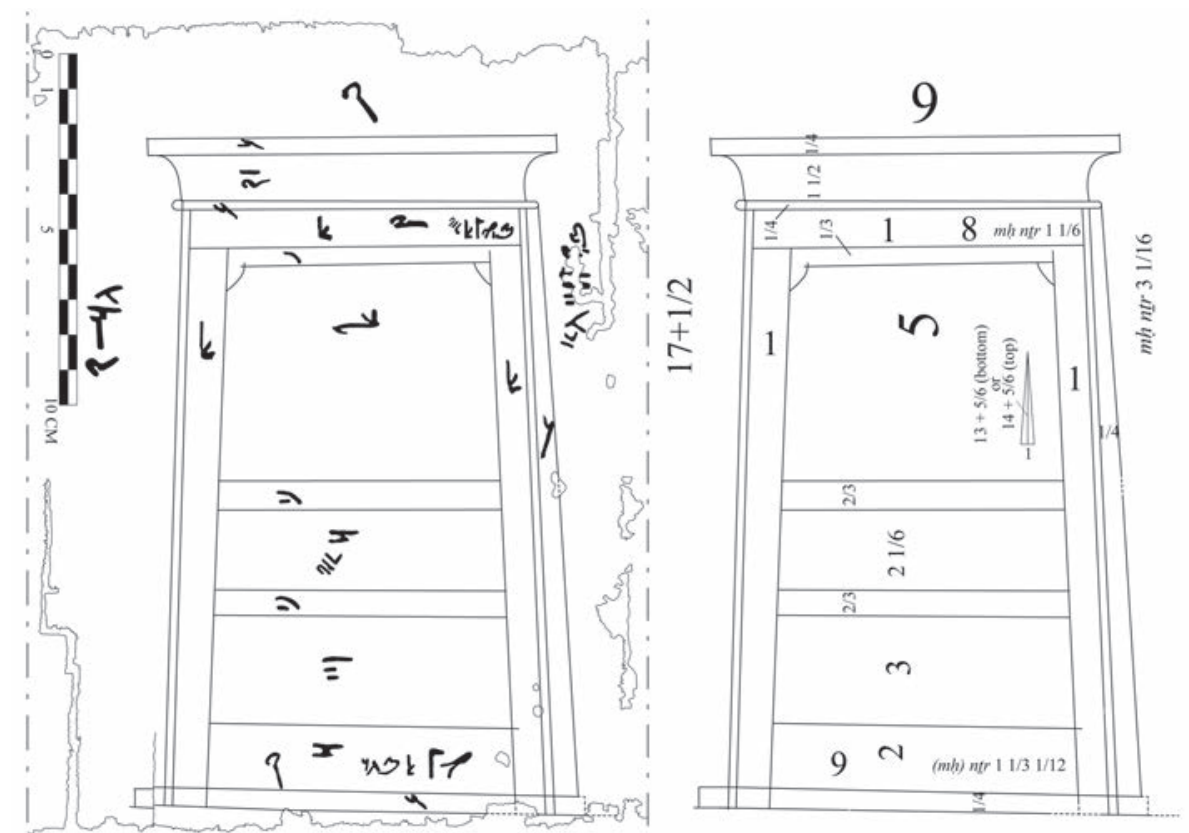

Fig. 2: An Elevation Drawing of a Shrine with Demotic Notations

(The Petrie Museum of Egyptian Archaeology, UC32374) 


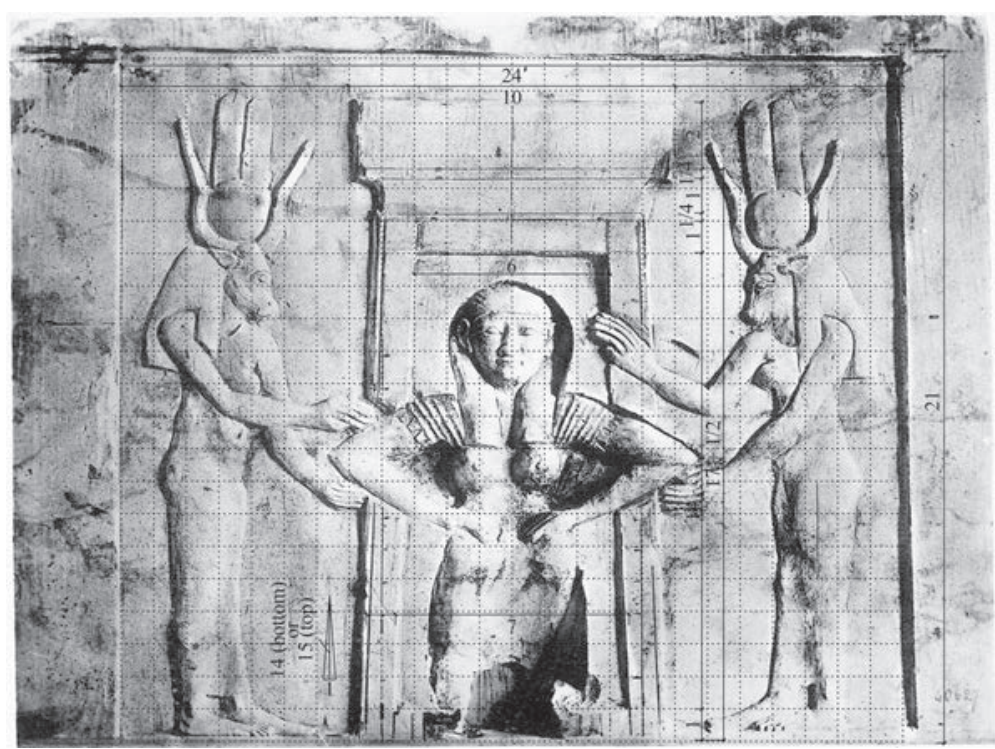

Fig. 3: A Depiction of a Shrine and a Goddess Giving Birth from Dendera

(CG40627: grid overlaid by author after Spiegelberg 1929, pl. 2. By permission of the Ministry of Antiquities, Egypt)

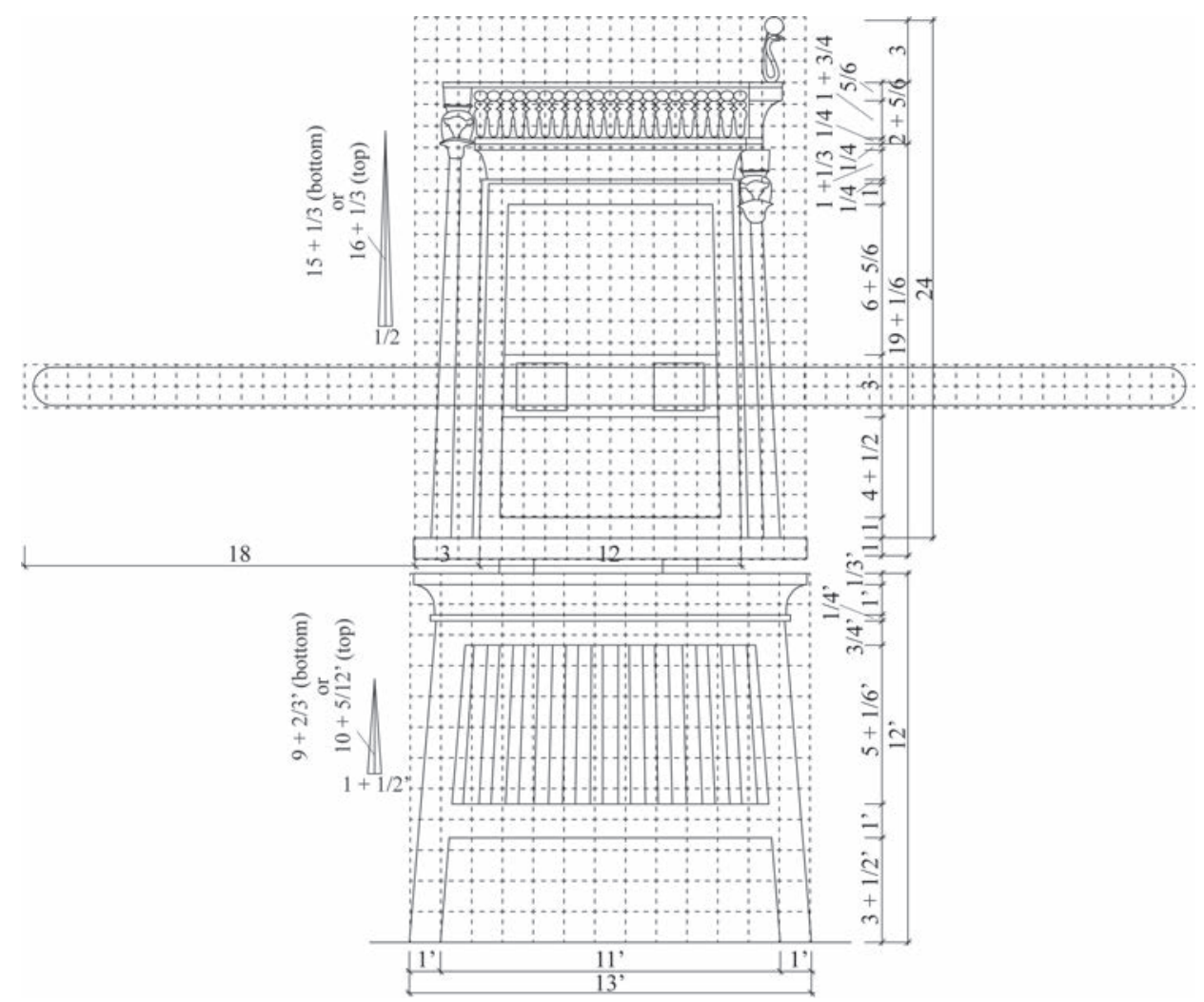

Fig. 4: A Depiction of a Shrine from a Temple-Wall in Athribis

(traced and grid overlaid by author after El-Sayed and El-Masry 2012, pl. 1) 


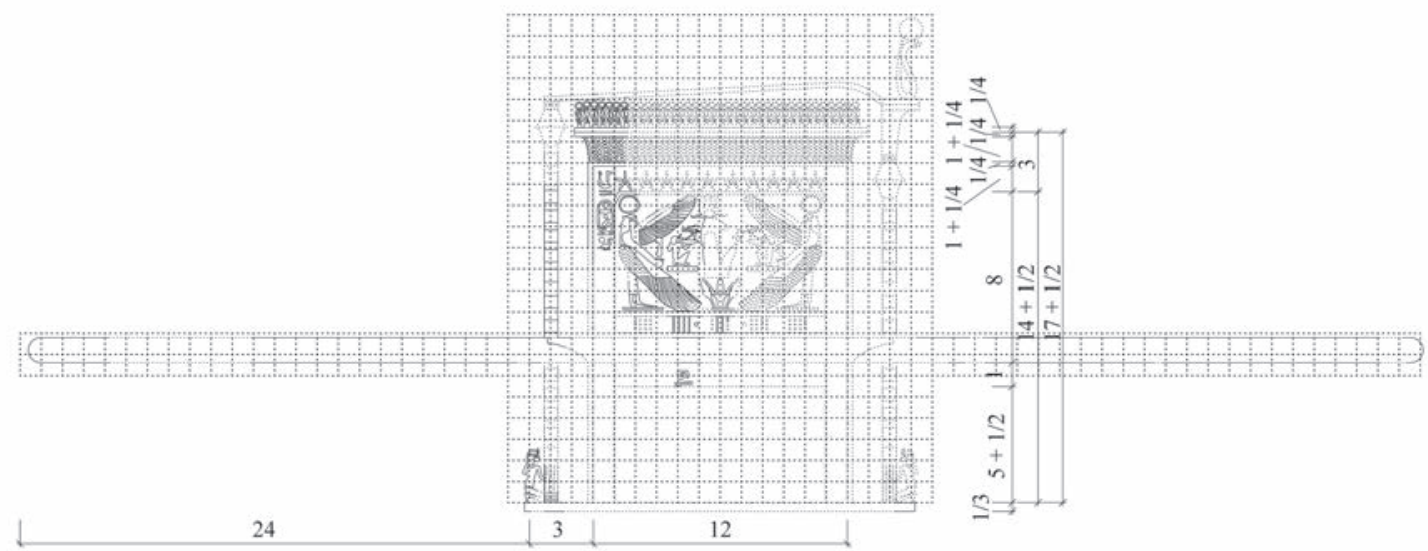

Fig. 5: A Depiction of a Shrine on the "Oracle Papyrus"

(Brooklyn Museum 47.218.3)

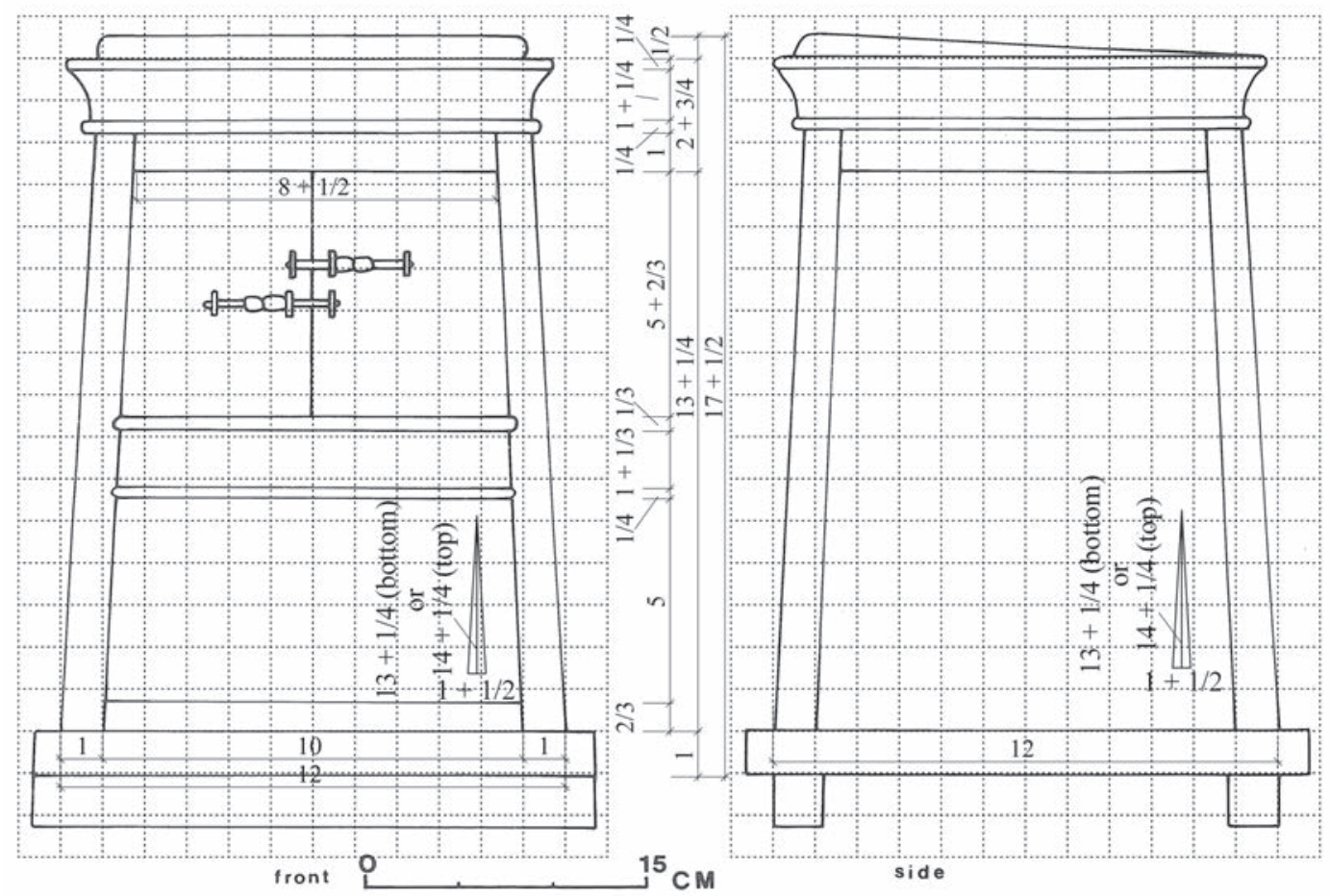

Fig. 6: A Wooden Shrine Found from the Animal Necropolis in Saqqara

(JdE91108: after Green 1987, fig. 4. By permission of the Egypt Exploration Society) 


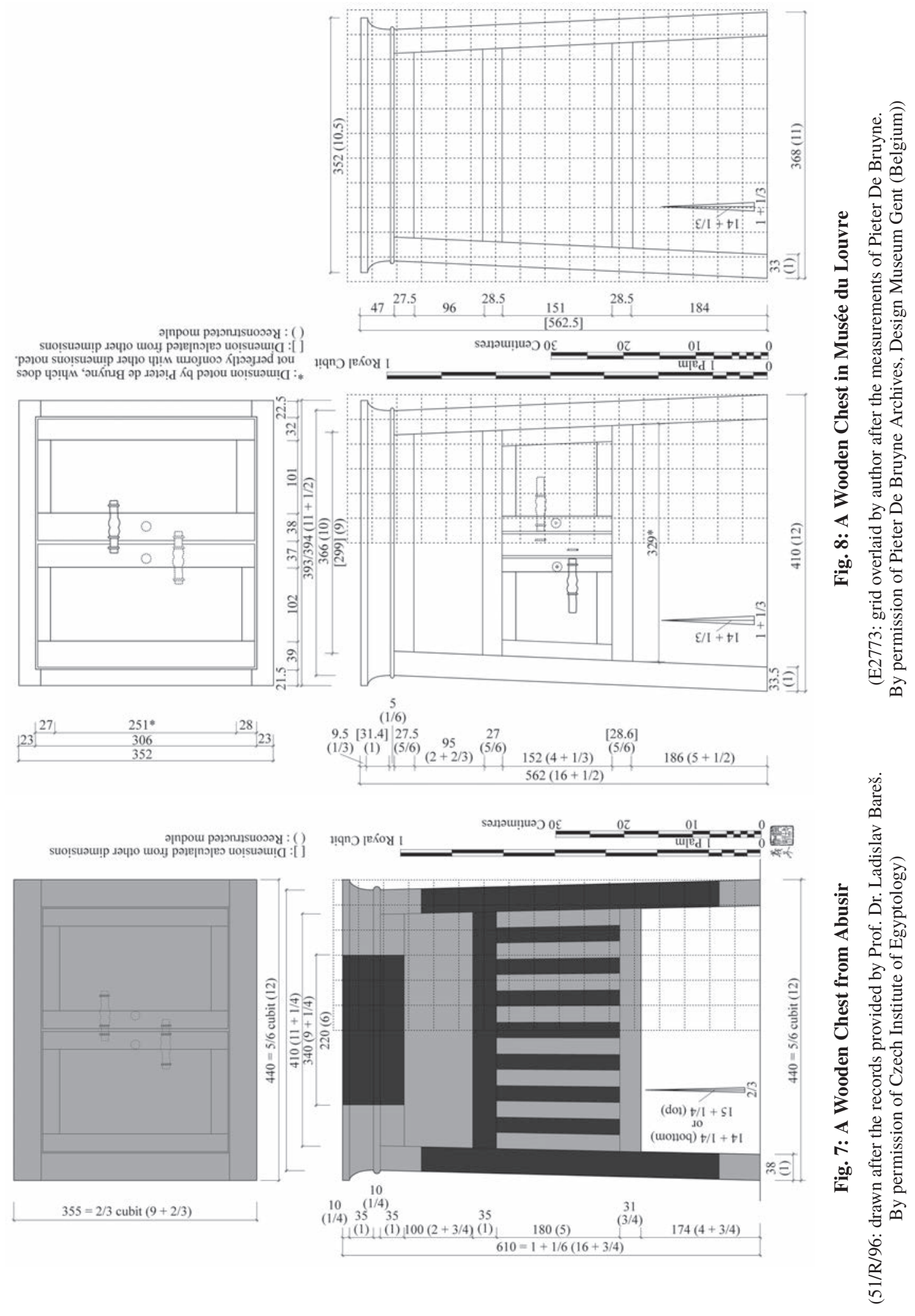




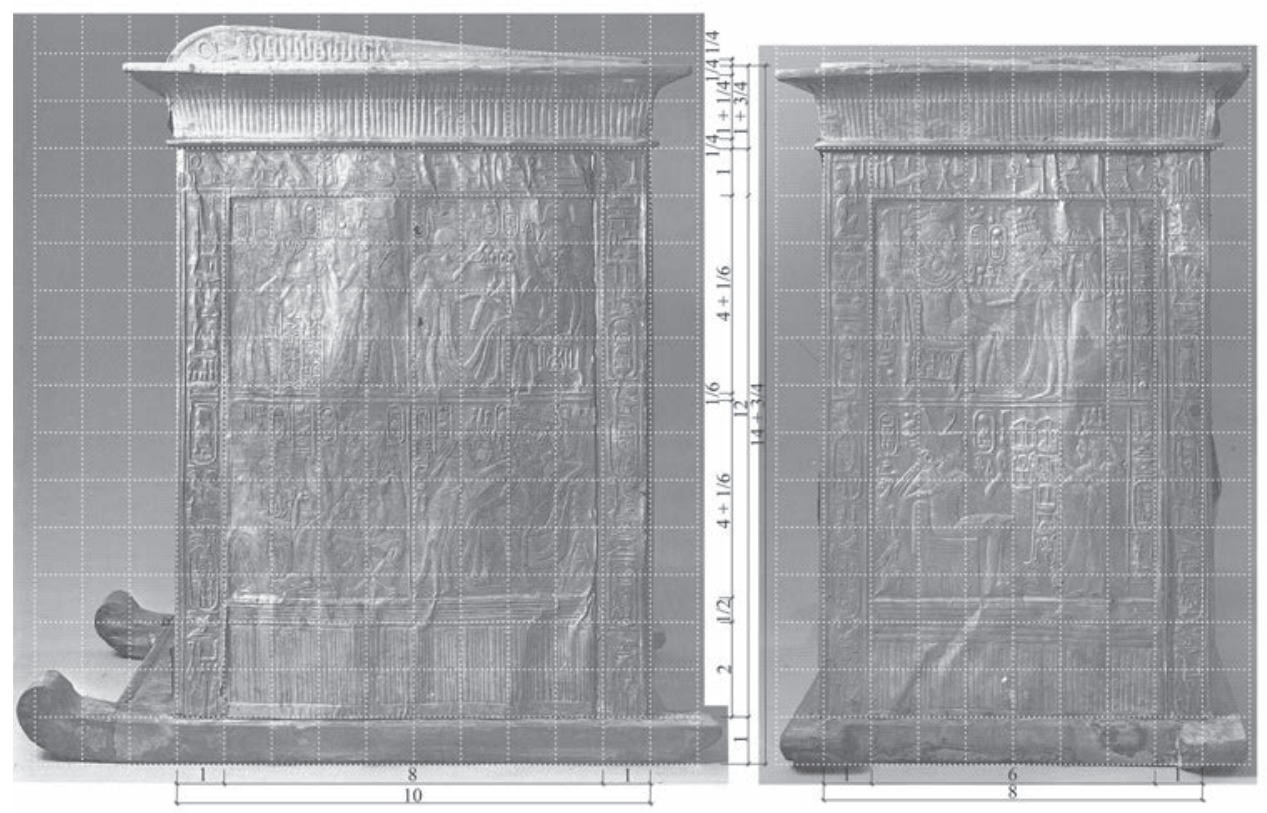

Fig. 9: A Small Shrine of Tutankhamun in Egyptian Museum in Cairo

(JdE61481: grid overlaid by author after the photos of Harry Burton p0314 and p0315. Courtesy of Griffith Institute, University of Oxford)

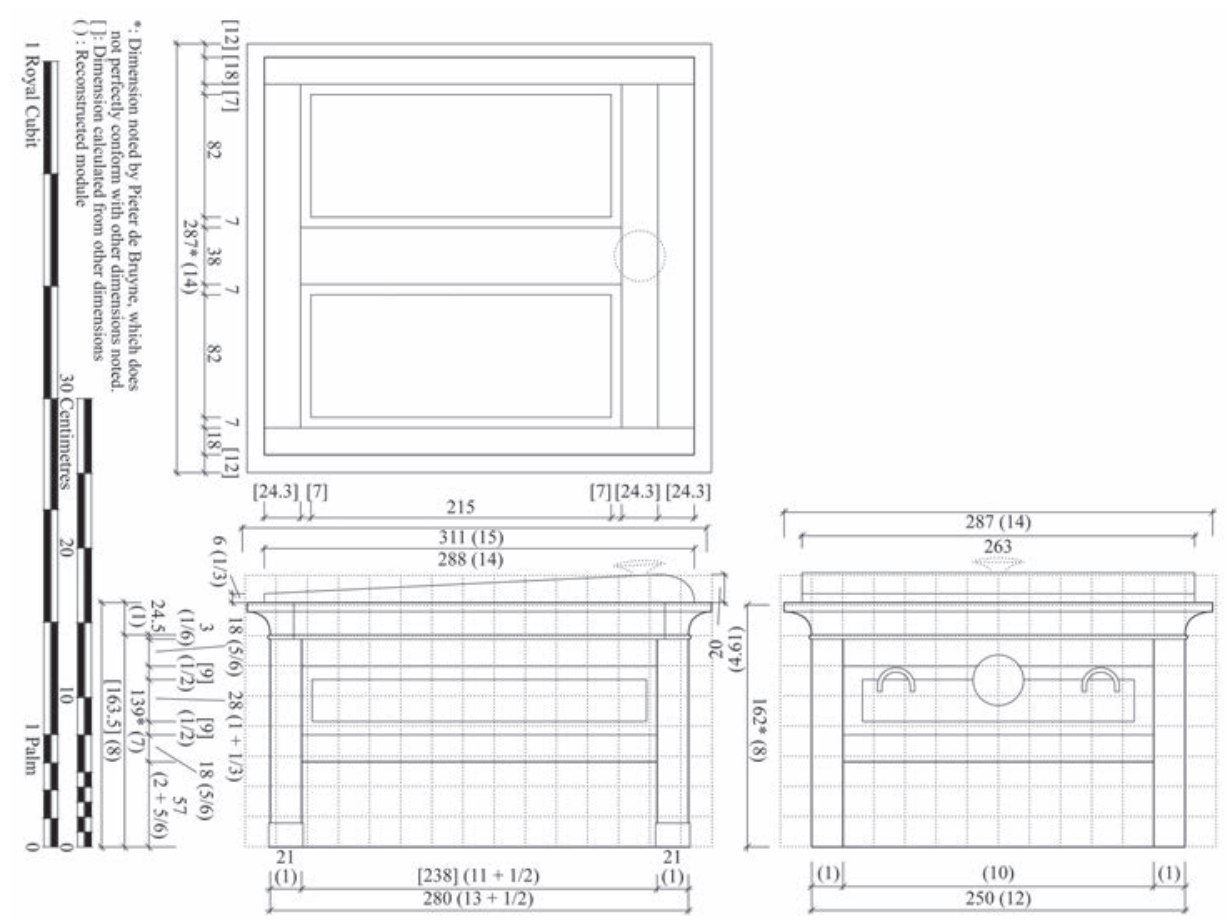

Fig. 10: A Chest of Tutankhamun in Egyptian Museum in Cairo

(JdE61480: grid overlaid by author after the measurements of Pieter De Bruyne. By permission of Pieter De Bruyne Archives, Design Museum Gent (Belgium)) 


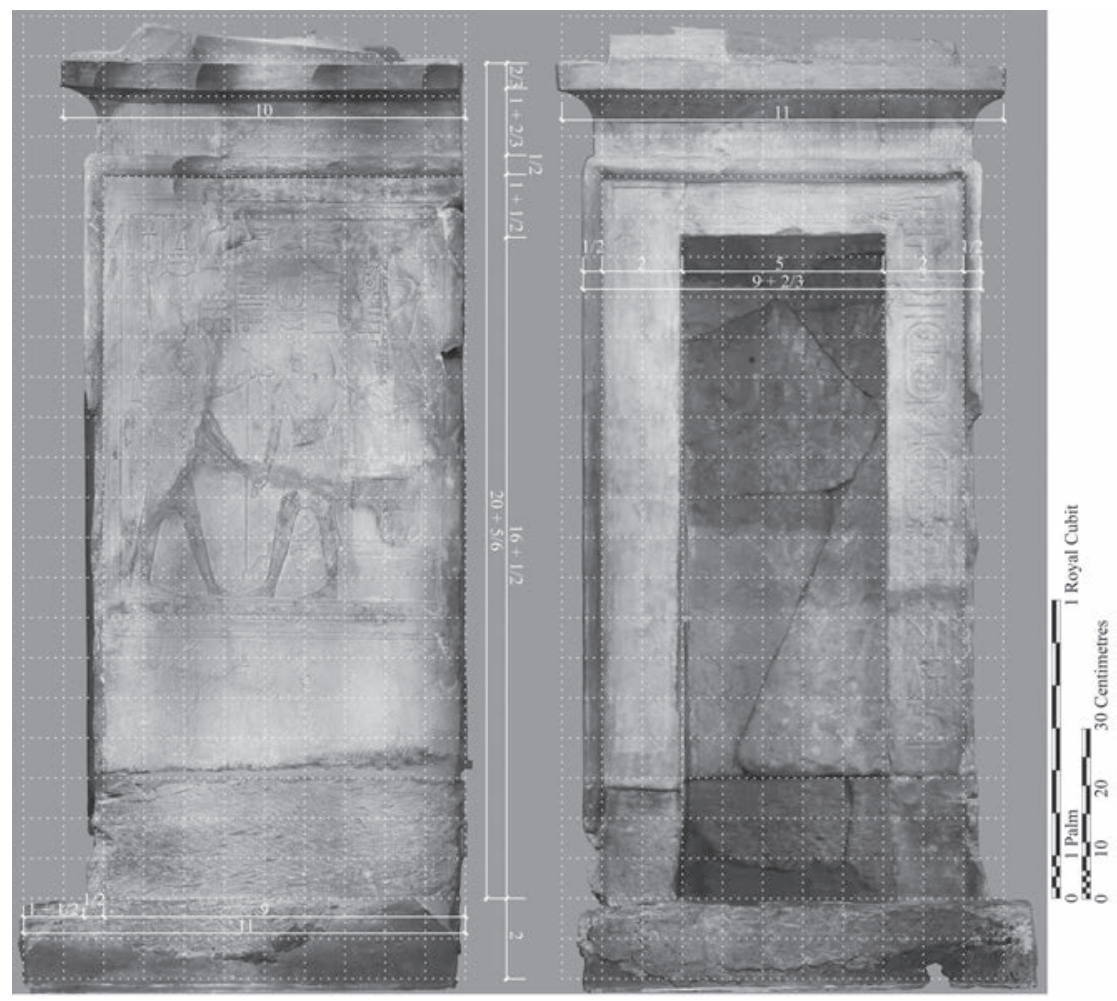

Fig. 11: A Stone Shrine of Thutmose III from El-Kab

(Fitzwilliam Museum E.40.1902: grid overlaid on the 3D-model made by photogrammetry. By permission of the Fitzwilliam Museum, Cambridge)
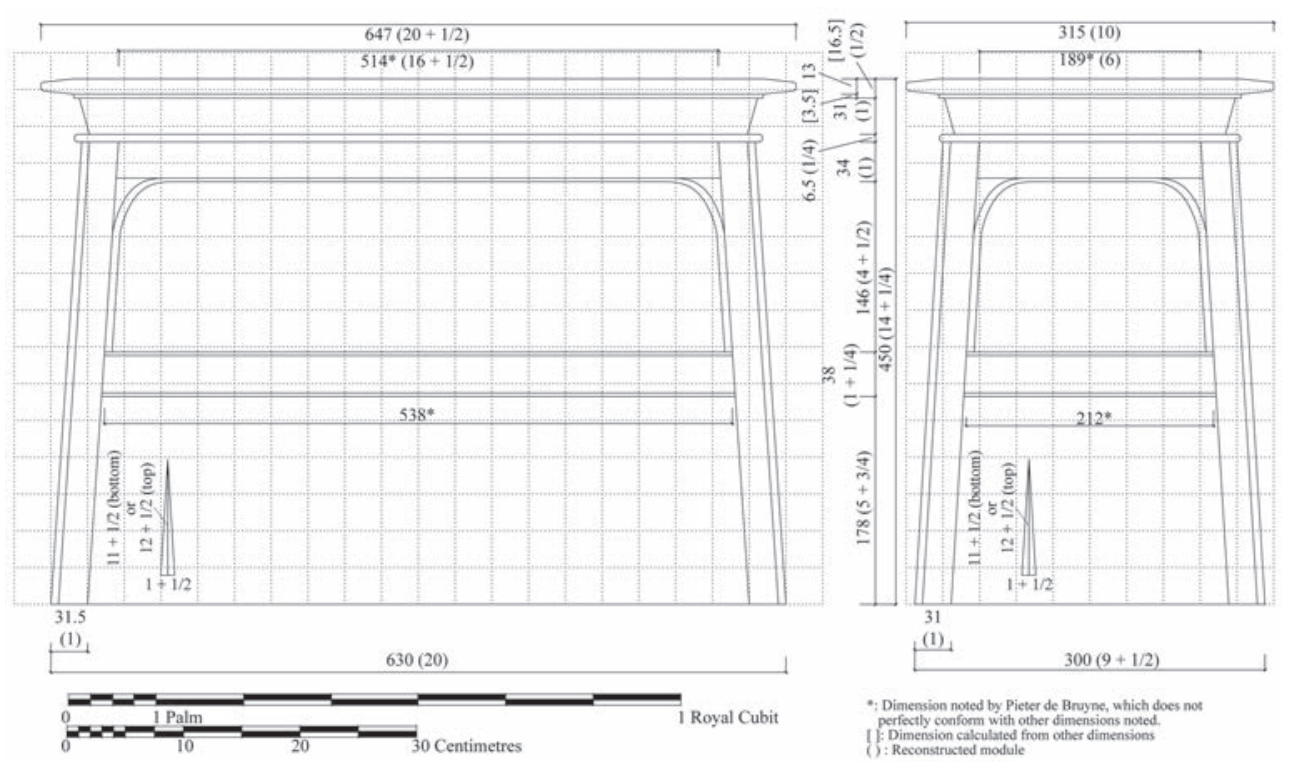

Fig. 12: A Wooden Table from el-Asasif in the Metropolitan Museum of Art, New York

(14.10.5: grid overlaid by author after the measurements of Pieter De Bruyne.

By permission of Pieter De Bruyne Archives, Design Museum Gent (Belgium)) 
Doric Temple Doorway (Vitruvius IV, 6.1-2)

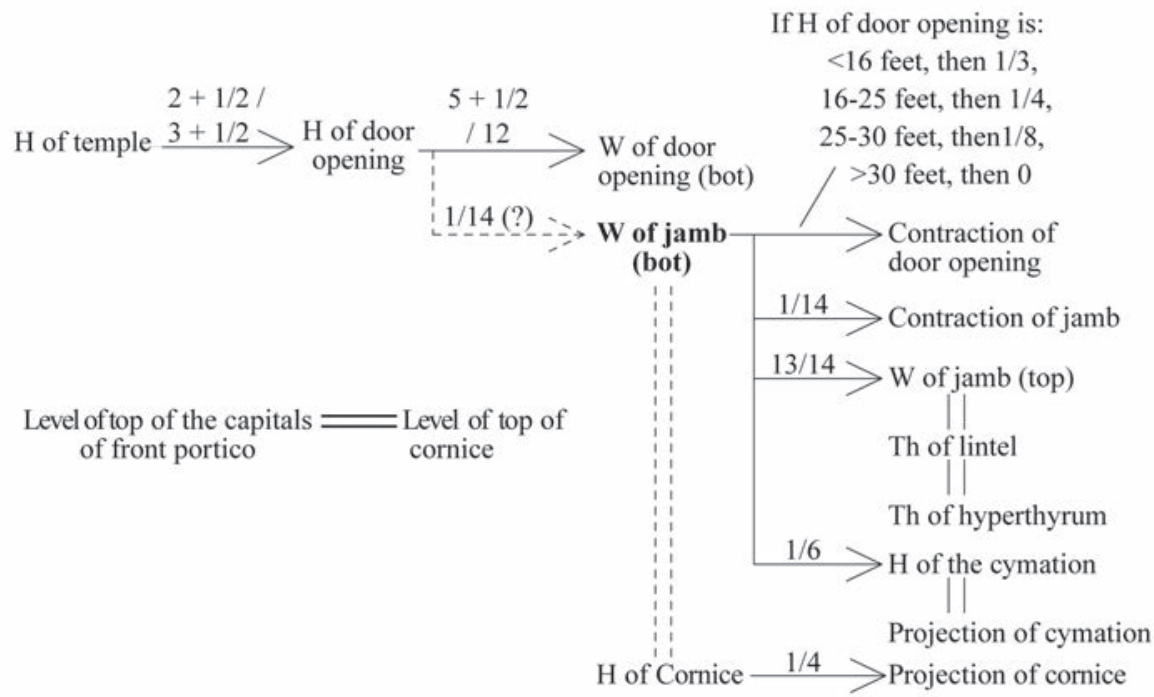

Fig. 13: Diagram of the Vitruvian Module System of Doric Doorway

Ionic Temple Doorway (Vitruvius IV, 6.3-5)

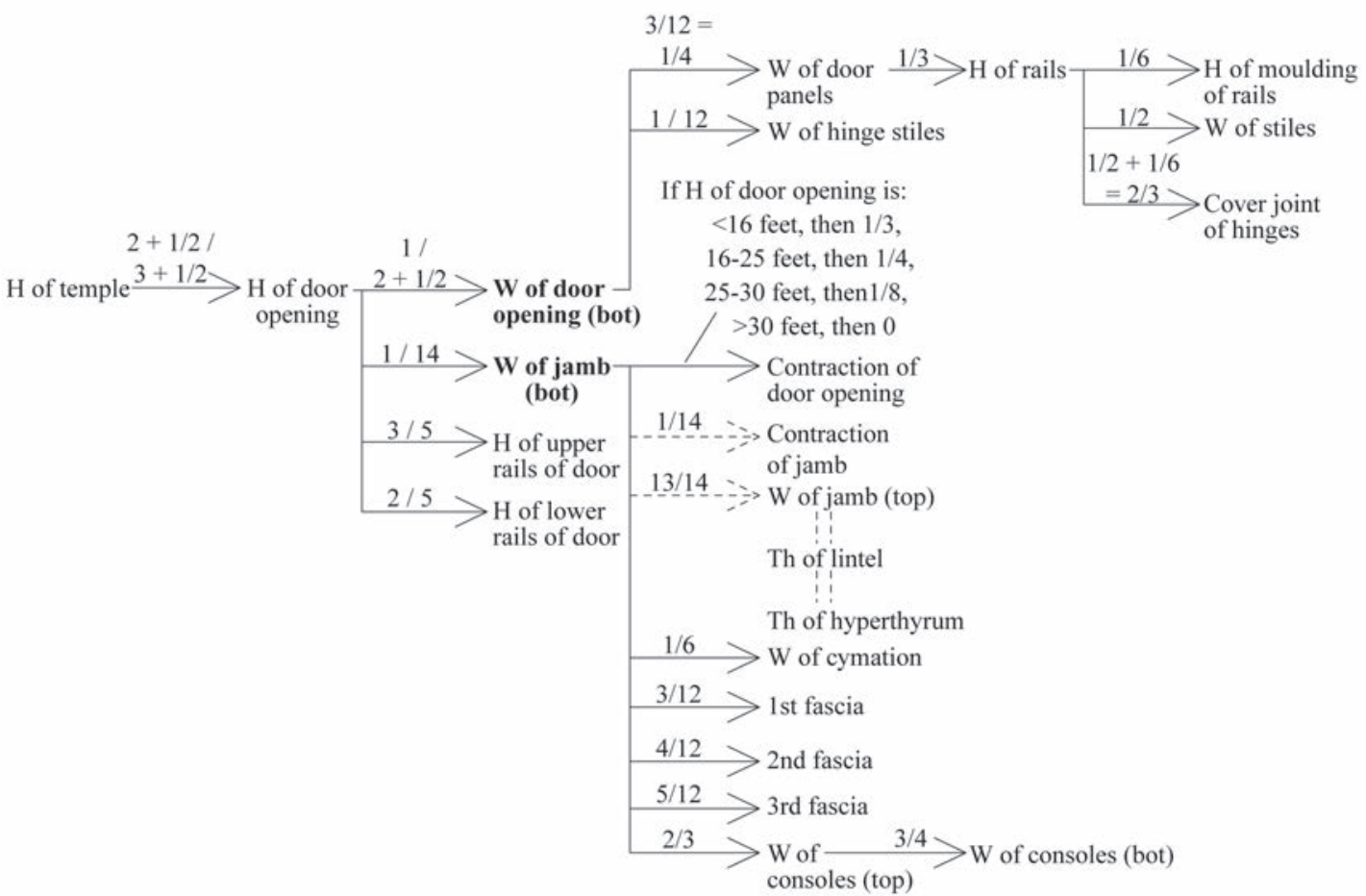

Fig. 14: Diagram of the Vitruvian Module System of Ionic Doorway 
Module System of the "Ghurob Shrine Papyrus" (reconstructed from the front view)

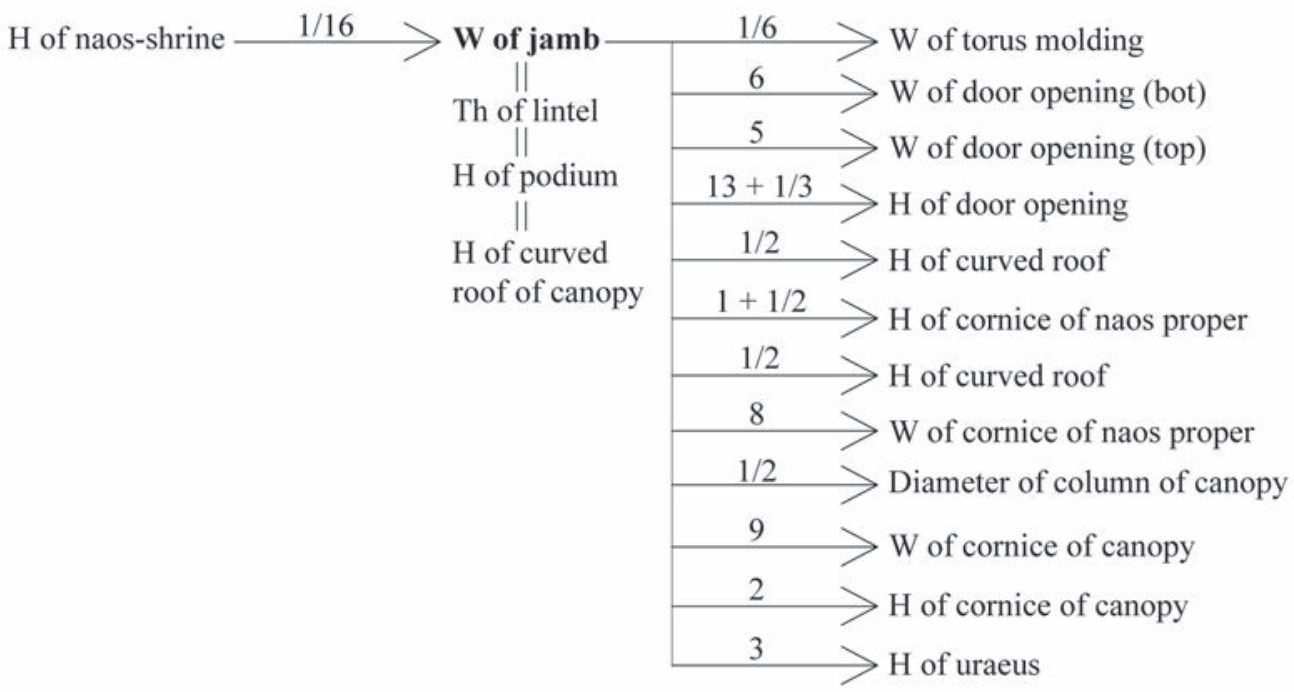

Fig. 15: Diagram of the Reconstructed Egyptian Module System of the Shrines 